\title{
ALS 者に対する入カスイッチの試み 第 4 報 Adaptation of input switch for ALS patient. Part. 4
}

\author{
河合俊宏 \\ 埼玉県総合リハビリテーションセンター \\ 相談部 福祉工学担当 \\ Toshihiro KAWAI \\ Rehabilitation Engineering, Department of Counseling \\ Sai tama Rehabilitation Center
}

1.はじめに

難病の一つの筇萎縮性側索硬化症 (Amyotrophic Latera1 Sclerosis：以下ALS）は、進行性の神経筋疾患である。知的 には障害を受けにくいことから、進行の程度によって、種々 の機器支援が有効となることがある。これまで、コミュニケ 一ション支援の一環として、手指の伸展方向の動きを利用し やすい患者に対して、設置を容易にするスイッチを試作し、 評価してきた。1)2》

今回患者への試行と、課題について報告する。

\section{2. 背景}

過去 13 年間において、コミュニケーション関連で在宅まで 訪問し、既に死亡された 17 例の中で、メカニカルスイッチを 利用したのは、12名であった。多くの場合は、メカニカルスイ ッチと、装具とを併用した形態で利用しており、身体を屈曲 する動作を用いてメカニカルスイッチを押し込み、意思を表 出してきた。しかしながら死亡例の中では 2 名、伸展する方向 での動作を、意図した信号として取り出す必要がある場合も あった。

\section{3. 試行例}

ALS 発症後 2 年。女性。四肢麻㾝で、右示指は随意的に動か すことが可能であった。入院中は、車いす上での評価で屈曲 動作を利用したスイッチを希望されていた。退院後はほとん ど寝たきり状態となり、腹部に手掌を置き、意思を伝えたい ニーズがあった。

在宅評価をしたところ、屈曲方向には充分な空間をとるこ とが出来なかった。試作装置による入力パルスの数によっ て、設置方向を利用者に説明した。試作装置とは、動きの方向 に、一定の張力をかけ、変位量を計測するセンサ（株式会社 ムトーエンジニアリング DX-025）を利用したものである。 1)

具体的には、屈曲方向に比べて、伸展方向が 8 倍の移動量が あった。

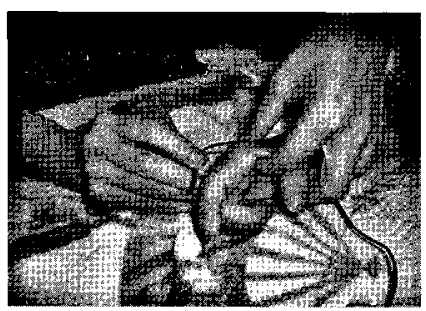

Fig. 1 評価
介助の関係で、複数名がスイッチの設定をすることから、接 触することでの市販スイッチを利用することとした。

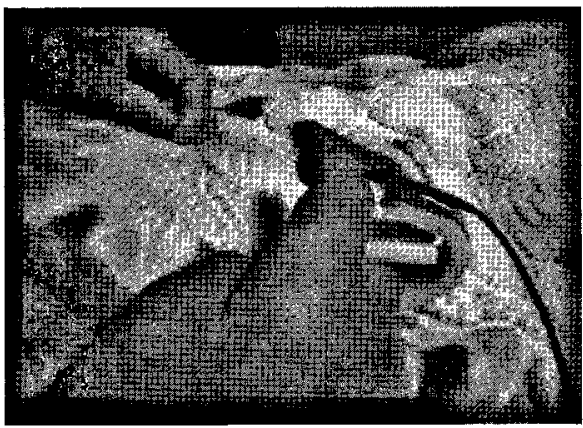

Fig.2 市販スイッチ

4. 考察

試作機器を継続評価してきたが、実際の患者に試したとこ ろ課題がらきぼりとなった。設計の前提として伸展・過伸展 であれば、指の重さを補うためにも一定の張力がある DX-025 を採択したわけであるが、今回の試行例では、屈曲も まだ可能な機能を示指が持っていたため、伸展方向を容易に 計測可能でも、遒入愔㛜しいものであった。

従来指先に傾斜スイッチを用いる場合には、スイッチの重 さが課題であったが、張力をかけるのも当然ながら同意であ る。過伸展動作であれば、自身の重さを相殺する機能となりう るが、関節の不安定性を圥長する可能性も否定できない。

今回採択したような接触式のセンサは、センサ自体の固定 能力によって、スイッチ設置のトラブルが発生してくる。自重 がかからないメリットと、だんだんとセンサ自身と稼働部位 とが離れていくデメリットとを勘案する必要性がある。

多種多様なスイッチ・センサの特性と、医療関係者の評価 とを、より結びつけることにより、ALS 者のスイッチ利用が搪 大し、介護者の設置がより簡易となるよう今後とも検討して ゆきたい。

本研究に関しては、本山悦子作業療法士に多大なる教示を受けた。 本研究の一部は、文部科学省科学研究費補助金（16091104）の助 成による。

参考文献

（1）河合俊宏，「ALS 者に対する入力スイッチの試み」，第 3 回生 活支援工学系学会連合大会講演予稿集. pp151;2005

（2）河合俊宏，「ALS 者に対扵る入力スイッチの試み 第 2 報」，第 4 回生活支援工学系学会連合大会講演予稿集. pp95;2006 